\title{
Free choice, modern love, and dependence. Marriage of minors and Rapt de séduction in the Austrian Netherlands
}

\author{
Bert De Munck \\ (University of Antwerp; Centre for Cultural and Urban History)
}

"L'amour est-il une exception, la seule, mais de première grandeur, à la loi de la domination masculine, une mise en suspens de la violence symbolique, ou la forme suprême, parce que la plus subtile, la plus invisible, de cette violence? ${ }^{11}$

\section{Introduction ${ }^{2}$}

The historical debate about marriage, love and family has long been limited to a dispute about the occurrence of fundamental change in the early modern age. Nowadays the issue is subtler and more complex, but the premise is often still 'modern versus pre-modern', or at least the past is seen in the light of modern versions of love, the nuclear family and marriage. ${ }^{3}$ The problem is, of course, that there is no consensus on the meaning of these notions, be it that one meaning seems to be dominating. Historians have often seen modern love as originating either in the re-emergence of a universal but for centuries suppressed inherent emotion, or from the absorption of tender, female values. Whether we are looking at England or the continent, and whether the origin of modern love is situated in the lower, the middle or the upper social classes, the implicit premise is that it arises as John Gillis concisely sums it up - from 'feelings rather than actions". 'Modern' is perceived in terms of 'romantic marriage', focusing on the private domain and revolving around the woman who is at the centre of that domain. ${ }^{4}$ In this light, one should expect ravishment either to disappear or to change character. Historians have especially located Raptus - the Latin for abduction - in the (late) Middle Ages, describing it as an opportunistic family strategy on the marriage market of which primarily women were the victims. ${ }^{5}$ In the eighteenth century one would expect it to be only a relic of old and disappearing customs. In reality, by the end of the Ancien Régime the French terms rapt and séduction had met in the juridical phrase rapt de séduction, literally meaning 'abduction through seduction' and used to denote marriages of minors without parental consent. ${ }^{6}$ The problem was not, however, an increasing licentiousness or individualism of youngsters wanting to choose their

\footnotetext{
${ }^{1}$ P. Bourdieu, La domination masculine, (Parijs, 1998), 116.

${ }^{2}$ I would like to thank Dr. Harald Deceulaer, Dr. Marc Jacobs and Prof. Dr. Hugo Soly for their stimulating criticism during my research on this subject.

${ }^{3}$ For a brief historical outline: Jeffrey R. Watt, The Making of Modern Marriage, Matrimonial Control and the Rise of Sentiment in Neuchâtel, 1550-1880, (Ithaca \& London, 1992), 1-23.

${ }^{4}$ An article that takes an original approach: John R. Gillis, "From ritual to romance: toward an alternative history of love", Emotion and Social Change, Toward a New Psychohistory, eds. Carol Z. Stearns \& Peter N. Stearns, (New York \& London, 1988), 87-123.

${ }^{5} \mathrm{Cfr}$. Henriette Benveniste, "Les enlèvements: stratégies matrimoniales, discours juridique et discours politique en France à la fin du Moyen Age", Revue Historique, 283 (1990), 13-35; Geneviève Ribordy, "Mariage aristocratique et doctrine ecclésiastique: le témoignage du rapt au Parlement de Paris pendant la guerre de cent ans", Crime, History \& Societies, 1 (1998) 2, 29-48. See also Danielle Haase-Dubosc, Ravie et enlevée. De l'enlèvement des femmes comme stratégie matrimoniale au XVIle siècle, (Parijs, 1999).

${ }^{6}$ For a first glance at the ambivalence of love, passion, seduction, contract and conflict: Pierre Hartmann, Le contrat et la séduction. Essai sur la subjectivité amoureuse dans le roman des Lumières, (Paris, 1998); Elena Pulcini, Amour-passion et amour conjugal. Rousseau et l'origine d'un conflit moderne, (Paris, 1998).
} 
future partners freely. Although a given word was crucial for ecclesiastic authorities, as parental consent was for secular courts, 'free choice' was not the issue. ${ }^{7}$

As far as the so-called 'conservative' continent is concerned, the persistency of patriarchal dominance and arranged marriage are taken for granted during the century of the French Revolution. ${ }^{8}$ Yet there has been relatively little fundamental research into the phenomenon of marriage of minors against their parents' will. Still, as the case of the Southern Netherlands proofs, research into rapt can be very rewarding. ${ }^{9}$ At least in the upper classes ${ }^{10}$, rapt de séduction was not a vanishing practice represented by a single surviving 'relic'. Not only did it reach a quantitative peak in the third quarter of the 18th century, it also appears to have been an extremely topical issue, with repercussions on even the highest circles of government. ${ }^{11}$ Rapt still involved a family strategy of which the minors, by the 18th century all those younger than 25, were the first victims. Examining the phenomenon more closely, it will moreover emerge that the third quarter of the 18th century experienced more than purely quantitative shifts. Before the late 1750's and after 1770 the situation was more or less stable, but between these two fairly precise traceable moments some characteristics changed. Firstly, we discover a slight shift in the social origin of the youngsters and the litigating families. Secondly - and this is the most salient finding - from the end of the 1750's women suddenly appeared as the seducing party almost as often as men. And thirdly, there was a conspicuous change in the sanctions imposed on the youngsters. Prior to the beginning of the 18th century the accent was placed on the punishment of the active, seducing party, but during the course of the century it was increasingly the passive, seduced party in a certain sense the victim - who was sanctioned with private confinement. This points to major mental transformations and psychological consequences diverging from any 'free choice' thesis.

Following recent developments in the social sciences, we will argue that scholars have often overlooked the concrete, practical and discursive situations contemporary individuals lived in. ${ }^{12}$ Francesca Cancian rightly pointed out, for instance, that the definition of love in terms of emotion and intimacy cannot be seen apart from declining chances on the labour market and increasing dependencies for women. ${ }^{13}$

\footnotetext{
${ }^{7}$ Consider Jean-Louis Moreau, "Mariages et conflits de génération à la fin de l'Ancien Régime, Brabant-Wallon", Wavriensia, 33 (1984), 1-26.

8 "For it seems likely that romantic marriage and the close association of parents with their children had made little headway in France or Italy. Patrilocal residence, arranged marriage and cicisbeature these were what an Englishman saw when he looked at the continental nobility after 1750, and he was either surprised or shocked. For he lived in a society where the possibility of social mobility (...) and the increasing equality of men and women made impossible the patriarchal dominance that was enshrined in the family patterns of the continental nobilities", Randolph Trumbach, The Rise of the Egalitarian Family. Aristocratic Kinship and Domestic Relations in 18th Century England, (New York, 1978), 288.

${ }^{9}$ For 'rapt' and 'seduction' in some neighbouring countries: H. Benveniste, "Les enlèvements"; R.B. Outhwaite, Clandestine Marriage in England, 1500-1850, (Londen \& Rio Grande), 1995; D. HaaseDubosc, Ravie et enlevée.

${ }^{10}$ The studied sources come from the archives of the highest secular courts. This means that we especially encounter persons and families from the elite groups. The results of this study must therefore not be transposed to other social classes.

${ }^{11}$ See Jean-Louis Moreau's extensive dissertation: La guerre matrimoniale, la sécularisation du mariage au $18^{\circ}$ siècle dans les Pays-Bas autrichiens, (licentiate's thesis), (Louvain-La-Neuve, 1983).

${ }^{12}$ See e.g. Theodore R. Schatzki, Karin Knorr Cetina and Eike von Savigny (eds.), The Practice Turn in Contemporary Theory, (Londen/NewYork 2001).

${ }^{13}$ Francesca M. Cancian, "The Feminization of Love", Signs: a Journal of Women in Culture and Society, 11 (1986), 692-709.
} 
Therefore, in stead of adding arguments pro or contra a growing individualism, an emerging freedom of choice or the inception of new disciplinary paradigm's, we will empirically focus on the relationship between 'actors' on the one hand and the context they lived in on the other. Youngsters as well as their parents faced numerous challenges and hindrances, and had several assets to cope with them. These assets could be financial, economic or social, but were at least as often cultural, moral or symbolic. In fact, we will see that none of these qualities should be regarded separately. In reality they were intertwined in interesting manners. Economic and symbolic properties featured simultaneously in the fierce negotiations between the conflicting parties, just as moral and social values did. In terms of the 18th century, birth and economic success could even be exchanged, and social and moral ideals were more or less synonymous. As a result, youngsters did not enforce progressive changes, but were trapped in the same pitfalls as their parents were. On changing circumstances they reacted somewhat regressively, and if they transgressed existing rules or norms, they often did so in line with their parents' wants. ${ }^{14}$ Focusing on the micro-level of social relations, we cannot but conclude that the freedom of action of both parents and children was limited, and that neither party decided consciously what strategy to follow.

\section{Rapt de séduction in the archives: a significant source}

Increase in the number of lawsuits

Especially after the strict ordinance of 1692 , minors who wish to marry without parental consent had no other recourse but to turn to the ecclesiastical court of a diocese, the court of the Officiality. Secular courts were no longer able to grant subrogated consent and the church, on the basis of the dogma of free will, took couples determined to marry under its wing..$^{15}$ In practice this also meant keeping them physically out of the reach of their parents, in a cloister or in the 'custody' of the diocese, so that the formal procedures required for the marriage could be concluded. ${ }^{16}$ The parents' only recourse was to appeal to a secular authority. Therefore, from the very beginning the conflict between parents and minors was locked within a fixed framework, which drastically influenced the course of any

\footnotetext{
${ }^{14}$ For the restraints on and the collective and public level of courtship behaviour: Diana O'Hara, Courtship and Constraint: Rethinking the Making of Marriage in Tudor England, (Manchester \& New York, 2000).

${ }^{15}$ For the legal aspects of the marriage of minors in the Southern Netherlands: Eugène Defacqz, Ancien droit belgique ou précis analytiques des lois et coutumes observées en Belgique avant le Code Civile, (Brussels, 1846-1873), 358-359; Leon Duguit, "Etude historique sur Rapt de Séduction", Nouvelle revue historique de droit français et étranger, 10 (1886), 587-625; John Gilissen, "Ouderlijke macht in het oud-Belgisch recht", Tijdschrift voor Rechtsgeschiedenis, 29 (1961), 484-506; John Gilissen, "Le statut de la femme dans l'ancien droit belge", Receuils Jean Bodin, XII, 2nd part, (Brussels, 1962), 255-258; Ph. Godding, Le droit privé dans les Pays-Bas méridionaux du $12^{\circ}$ au $18^{\circ}$ siècle, (Brussels, 1987); G. Pacilly, "Contribution à l'histoire de la théorie du Rapt de séduction. Étude de jurisprudence", Tijdschrift voor Rechtsgeschiedenis, 13 (1934), 306; Maurice Yans, "Textes Liégois relatifs au rapt et au consentement paternel", Annuaire d'histoire liégeoise, 4 (1974), 23-49. For earlier centuries, legislation in neighbouring countries and the (primarily canon) law, see the extensive footnotes in Myriam Greilsammer, "Rapts de séduction et rapts violents en Flandre et en Brabant à la fin du Moyen Age", Tijdschrift voor Rechtsgeschiedenis, 56 (1988), 49-84.

${ }^{16}$ After the Council of Trent, two aspects were important for the church: the presence of a priest (and two witnesses) and the prior announcement of the marriage in the banns. Only the lack of the first resulted in the invalidity of the marriage.
} 
litigation. The outcome of a lawsuit depended to a great extent upon the precise balance of power between the ecclesiastical and the secular authorities. At the end of the Ancien Régime, the complex conflict in which they were embroiled evolved towards a climax. ${ }^{17}$ The stakes, particularly as far as the marriage of minors was concerned, were considerable. In 1763 the magistrates of Bruges even took their grievances about the ecclesiastical court directly to Vienna: "a mere promise of marriage, given by a minor in the folly of youth or in the blindness of passion, confounds all the maternal care of Her Majesty (...) on the strength of this, an ecclesiastical court forces them to marry (...) despite the inequality of station, the reprehensible conduct of either or both of the parties, the opposition of the father and mother, and the inevitable ruin of entire families and little by little also the state, which to no small degree is sustained by alliances in keeping with the station of the contracting parties." 18

For the period between 1700 and 1784, the year in which Joseph II radically amended the marriage laws, we could trace a total of 90 dossiers, all of which were the result of lawsuits brought before the higher secular authorities. ${ }^{19}$ At first sight, 90 dossiers in 84 years does not seem uncommonly many. Their number only becomes of interest considering the almost exclusive involvement of people from the elite groups and, above all, the rising trend. Since we have not exhaustively examined ecclesiastical archives and since a gradual shift from ecclesiastical to secular courts was taking place in this matter, it is difficult to determine what kind of change exactly occurred. It is however clear that the formal shift was already becoming apparent in the 17th century, whilst in our sample the turning point only comes in the 1750's. Compared with the second half of the 17th century (23 dossiers), the number of dossiers in the first half of the 18th century was still declining (16 dossiers), which only makes the increase in the second half of the 18th century all the more striking (no less than 74 dossiers between 1758 en 1784). To put it another way: although the annual average from 1700 up to 1758 is only 0.4 law suits per year, it has already risen to 3.3 between 1758 and 1768 . We must not forget here that during the first period the figures were distorted by both the Spanish and the Austrian Wars of Succession, but between 1748 and 1758 the average was 0.8 law suits per year, and that still stands in sharp contrast to the 3.3 of the ten following years.

\section{Youngsters: meetings and meeting places}

Yet more important and less influenced by the conflict between ecclesiastical and temporal authorities, is the nature of the dossiers. Although this kind of source invites an interpretation in terms of a generation conflict or the disciplining of youngsters, this does not appear to tally with reality. The thesis that there was a polarisation of 'youngsters' and parents is difficult to defend. To begin with, as is already ascertained for previous centuries ${ }^{20}$ the root cause of these lawsuits is not the fact that young people were choosing partners unknown by their parents. Of the 31 cases in which we were able to discover where the two sweethearts had met for the first time, in 16 cases this was simply at home: one time at the boy's parental home,

\footnotetext{
${ }^{17}$ See J.-L. Moreau, La guerre.

${ }^{18}$ G.S.A.B., Austrian Chancellory for the Southern Netherlands, Vienna, box 466 (original), copy in box 1299/A, 12 June 1763.

${ }^{19}$ The authorities concerned are the Privy Council, the Grand Council of Mechelen, the Council of Brabant ("Officie Fiscalen") and the Council of Flanders.

${ }^{20}$ Namely for France: see H. Benveniste, "Les enlèvements", $19 f f$.
} 
the other 15 at the girl's parental home. In another four cases it turns out that the first meeting occurred at the convent where the girl was residing (before any problems arose). Of the remaining eleven meetings, one took place in a boarding house where both young people were staying, and another at an academy where both were studying. One meeting took place at a once-only military parade and in the case of eight couples we know little more than that a student in Louvain, the university city, was involved. But even then it was sometimes the case that boy and girl were simply lodging in the same boarding house. Ultimately we are left with one case in which they met somewhere in town, probably at an inn or a tavern. In other words, only around the university of Louvain the possibility that the origin of these dossiers must be sought in changing courtship habits of the younger generation, still remains open. A phenomenon such as London's "Fleet Market", a place which had the bad reputation of being a breeding ground for clandestine marriages, did not exist in the Austrian Netherlands. ${ }^{21}$

Many partners even knew each other since their very childhood ("depuis leurs tendre jeunesse"). In more than half of our cases we can state with certainty that the suitor came from the same village or from the family's circle of friends. Only in 16 dossiers we can state with equal certainty that this was not the case. ${ }^{22}$ At least in nine of these, moreover, the fact that the parents did not know 'the name and faculties of the suitor' was precisely the most important objection to the marriage. All this indicates it as an exceptional situation. Not coincidentally, the almost despairing question 'How on earth is it possible that they could have become acquainted?' resounds in a limited number of law suits. ${ }^{23}$ Sometimes it seems that the young couple got to know each other solely via the smuggling of letters and that they had barely ever seen each other at the moment they plighted their troth.

Adding to this, when the number of lawsuits increased in the second half of the century, there was definitely no corresponding increase in the number of dossiers in which the parents did not know the suitor in question. A change in courting customs or in the behaviour of marriageable people can therefore hardly have been the cause of this increase. For that matter, once the youngsters had escaped parental control, they usually hastened to a cloister, which proofs they didn't have recourse to a subculture of like-minded peers. In a few cases they attempted to 'go it alone', but this quickly turned into aimless wandering, which they themselves later bemoaned. ${ }^{24}$ Lodging with friends or in inns was not an option.

\section{Seduction: who is seducing whom?}

The argument that the greatest tension is not to be found between the couple and their respective parents is supported by other aspects. In the first place, there was a striking age difference, not when calculating the average age of every men and women in the dossiers, or between the ages of those marrying and the average age

\footnotetext{
${ }^{21}$ The heyday of the Fleet Market was in the 1730s and 1740s. Everything from inns up to and including priests was on hand to attract those eager to marry. The famous Hardwick's Act had a lot to do with its decline after 1750. See R.B. Outhwaite, Clandestine Marriages; Roger Lee Brown, "The rise and fall of the Fleet Marriages", in Marriage and Society, Studies in the Social History of Marriage, ed. R.B. Outhwaite (London, 1981), 117-137.

${ }^{22}$ For the remainder we could not establish the background of the suitor with sufficient certainty.

${ }^{23}$ See for example Ghent State Archives (hereinafter G.S.A.), Council of Flanders (J. Buntinckx), 23 181, Baudinne/Remy, 1740.

${ }^{24}$ G.S.A., Council of Flanders, 23 532, 1780 .
} 
of marriage, but between the seducer and the seducee. ${ }^{25}$ In the law suits in which the ages of both parties is mentioned, this difference amounts to no less than 9.3 years, while the difference between the average age of all the men (23.3) and of all the women (21.1) involved is only 2.2 years. The stakes only become clear splitting the average age into 'the seducer' and 'the seducee'. For the seducee, the minor, the average age was 21 years, which is strikingly lower than the 24 to 27 years generally accepted as the average age of marriage for girls. Of course, the youth of the seducee can be attributed to the nature of the source, but after 1760 their age was still falling (20.1), although it is generally accepted that the average age of marriage in the 18th century was rising. The average age of the seducer (or seductress, given the fact that this party may be either a man or a woman) was 28.7 , which is relatively high but not exceptionally so. ${ }^{26}$ Distinguishing between men and women in these average ages, we find seduced young men on average 20.6 years old, seduced young women 20.5. For the seducer/seductress the difference was greater: 29.5 for men, 26.6 for women. ${ }^{27}$

What can we deduce from all this? Firstly, that it is worthwhile distinguishing between the active and the passive party beyond the legal logic. Secondly, 'marriages of convenience' can have played an important role. After all, thanks to his or her age, the older party probably had more reasons to enter into a permanent union. Thirdly, it is not inconceivable that one of the partners was more dominant from the very beginning. In a number of cases, for example, one of the two partners themselves ultimately no longer wanted to marry. ${ }^{28}$ For the church, however, the promise of marriage had to be fulfilled regardless. Abuse was an obvious possibility here.

The most striking indication that the conflict was not a generational one, however, is the active input of various sets of parents. With the aim of ensnaring a minor, real campaigns of seduction were launched, either via a (usually written) pledge, or via sexual intercourse.$^{29}$ The first (clear) example of this occurred in 1749, when the Van Der Laenen family conceived a plan to marry a son to Marie Verspecht, an orphan who lived in a convent. One day, for no apparent reason, she was honoured with a visit from almost the entire Van Der Laenen family, and such visits were repeated more regularly in the following. The Van Der Laenen's even went so far as to conduct the sixteen-year-old orphan to a nearby inn, where she was then left alone with their son. ${ }^{30}$ After the late 1750 's, similar family efforts seem to have become more frequent. The father of the Wreckem family used legal and extra-legal means to ensure the marriage of his daughter and the young de Butler de la Branche after the couple had themselves taken the initiative to flee the 'Academie de Lille'. After he

\footnotetext{
${ }^{25}$ For the sake of convenience, we shall also distinguish between the 'seducer' and the 'seducee' further in this article. This distinction stems primarily from the juridical logic of the law suit. The seducee is usually the under-aged son or daughter whose parents are opposing the marriage.

${ }^{26}$ More general data about the Southern Netherlands can be found, amongst other places, in Chris Vandenbroecke, Sociale geschiedenis van het Vlaamse volk, (Beveren, 1981); Chris Vandenbroecke, Vrijen en trouwen van de middeleeuwen tot heden; seks, huwelijk en liefde in historisch perspectief, (Brussels \& Amsterdam, 1986).

${ }^{27}$ These statistics were only registered after 1760 .

${ }^{28}$ It is naturally often unclear in how far reluctance to marry was inspired by parental pressure.

${ }^{29}$ This of course does not rule out the possibility that the parents of minors were also actively involved in bringing many marriages, on the contrary. Although in the law suits referred to here the parents of the minor were by definition opposed to the marriage, it was sometimes the case that they meanwhile had another candidate lined up, and even that they originally introduced the partner to whom they opposed later on.

${ }^{30}$ G.S.A., Council of Flanders, 23 268, Van Der Laenen/Verspecht, 1749.
} 
himself was sequestered and thus powerless to act, the son de Butler ultimately came to rely entirely upon the girl's father. The latter even went so far as to send paper so that the boy could write to her from his cell. He even wrote to his daughter himself in the name of the young nobleman. ${ }^{31}$ Next, in 1759, we come across the seduction of the 'simple-minded' Antoine Plantefeve by Dorothee Block, most probably with the full support of her family, ${ }^{32}$ and one year later the father of François Garcie clearly had a hand in the abduction of Louise Reyvaert. ${ }^{33}$ Later in that same year, from Spain, an adult (but nevertheless seduced) young man granted a mandate to his seductress's father which enabled him to marry the girl by proxy. ${ }^{34} \mathrm{~A}$ more significant conflict, also politically, is the lawsuit brought by the de Neve family against the private schoolmaster Josse Ridderbosch between 1763 and 1766. The latter had almost literally put his daughter at the disposal of the young nobleman de Neve, who had been entrusted to him since the age of twelve. A number of witnesses even claim he orchestrated the moment the young nobleman made his daughter physically his own, by sending the couple upstairs as they were gathered at an inn with some acquaintances. Ultimately, however, he seems to have gone too far, at least that is the conclusion we can draw from the testimonies which claim that thanks to the whole affair he was obliged to close his school. ${ }^{35}$ At the same time a lawsuit against the family Wautier, rich merchants who had set their sights on somebody from the aristocratic family Limnandes, was also in progress. ${ }^{36}$

After this it was not until 1767 that a similar case appeared. The young D'Hane de Jolimont acknowledged his promise of marriage ("a avoué sa promesse") after his mistress and her mother had together reminded him of it. Remarkably enough, the young man did not even have a good reputation. At a young age he had been confined in the 'Maison Forte' and at the time of the lawsuit he was still facing difficulties in avoiding a new private confinement. Yet the reason the mother so resolutely sided with her daughter does not take much looking for. The social gap between the two families was so great that such a marriage must have seemed nothing short of a miracle. Significantly, it was the young man himself, who must at first have said that he didn't look at differences of station ("dat hy naer geen distinctie van persoonen sagh"), who ultimately wisely backed out. ${ }^{37}$ But already less than a year later, it was again the so-called 'criminal complaisance' of a girl's parents ("la criminelle complaisance des parents de cette fille") which provoked a lawsuit. This time the only son of the De Zomberg family was the willing victim. The opposing Ghislain family was still claiming the validity of the marriage five years later. ${ }^{38}$ Still in 1768 , the son of the senior magistrate de Keerle ("Haut Pointre de la Chatellenie d'Oudenaerde") let himself be ensnared, not only by Marie-Thérèse Deurwaerder, but by virtually her whole family, led by her stepfather, a senior financial official ("Conseiller Receveur General") to the Council of Flanders. Here too the seduced youth had a rather bad reputation. ${ }^{39}$ In 1769 it was a law student at Louvain

\footnotetext{
${ }^{31}$ G.S.A.B., Privy Council, 650/B, Butler de la Branche/Wreckem, 1757.

${ }^{32}$ G.S.A.B., Privy Council, 1298/A, Plantefeve/Block, 1759.

${ }^{33}$ G.S.A., Council of Flanders, 23 368, Garcie/Reyvaert, 1760.

${ }^{34}$ G.S.A.B., Privy Council, 1298/B, Rooman/Cazeele, 1760.

${ }^{35}$ G.S.A.B., Privy Council, 1298/B, de Neve/Ridderbosch, 1763.

${ }^{36}$ G.S.A.B., Privy Council, 1298/B, de Limnandes/Wautier, 1763.

${ }^{37}$ G.S.A.B., Privy Council, 1299/A, D'Hane/Van Loo, Extrait de protocole of the Privy Council, 14/12/1767.

${ }^{38}$ G.S.A.B., Privy Council, 1300/C, Ghislain/De Zomberg, Recommendation to the Privy Council, 3/7/1768.

${ }^{39}$ G.S.A.B., Privy Council, 1298/B and 1299/A, Deurwaerder/de Keerle, 1768.
} 
University, the son of Chevalier van Outheusden, who met the daughter of a lawyer at a military parade. He spent the whole day with the girl until her parents arrived to collect her from the inn. What exactly happened that day is not entirely clear, but the twenty-two year old young man was obliged to sign a promise of marriage with a price: 30,000 guilders. According to the girl's parents, the young nobleman had seduced her, yet it was Chevalier van Outheusden who opposed the marriage. Indeed, it is not inconceivable that the girl's family used her to ensnare the young nobleman, especially when we consider that for girls of her station the chances of spending time alone with strange men were extremely slim. ${ }^{40}$ In any case, only after 1770 passions seem to have cooled. In the Wymeersch/Broodcoren dossier an uncle of the girl (seductress) did join her in her petition that the marriage should go ahead, ${ }^{41}$ and in 1776 there was "Lovendeghem et sa famille" whose efforts to ensure a marriage were suspiciously great, but after that it was not until 1782 before we meet another case of an entire family taking into its protection a girl who had run away from home. ${ }^{42}$

Myriam Greilsammer situates rapt de séduction (in the late Middle Ages) within a framework of primarily female resistance to family strategies; indicating a kind of struggle for freedom. ${ }^{43}$ In the Austrian Netherlands it wasn't that simple. Understanding the illegitimate marriage in terms of 'seduction', it will become apparent that the question of whom was seducing whom, is far from innocent. In most cases the seducee was a minor girl, suggesting that her role was quite passive and that her 'act' was all but a sign of a growing sense of freedom or individuality. Young girls were either under the powerful influence of their parents - as in the case of Joanna Ridderbosch - or they were more or less controlled by a much older 'seducer', if not his whole family. Only in a minority of the dossiers do we learn anything about the parents of the seducer/seductress, but each time that we do they unequivocally supported their child, whatever she or he was up to. In most cases it was precisely the silence of the family of the seducer/seductress that is striking. ${ }^{44}$ We can assume they often also approved of, or even financed, the actions of their son or daughter. ${ }^{45}$ After all, trapping a girl of a higher station, must have generated a kind of prestige in the $18^{\text {th }}$ century. Some even referred to rapt de séduction in terms of an act 'to which the corruption of morals has almost given the name of gallantry"' ${ }^{46}$

\footnotetext{
${ }^{40}$ G.S.A.B., Privy Council, 1299/C, Van Outheusden, 1769. From an almost casual remark we know for example that Françoise de Fusco could only attend church after consulting her father and even then only when accompanied by an older, male relation: G.S.A.B., Council of Brabant, 8236, de Fusco/Hulden, 1710

${ }^{41}$ G.S.A.B., Privy Council, 1300/C, Wymeersch/Brootcoren, 1773

${ }^{42}$ G.S.A.B., Council of Brabant, 9732, Janssens/Coenen, 1782.

43 "Le rapt comme seul echappatoire à un mariage forcé...". M. Greilsammer, "Rapts", 81. See also Michel Porret, "La 'jeune fille mal gardée' ou le ravissement de Colette Schweppe. Anatomie d'un Rapt de séduction au XVIIlle siècle", Equinoxe, (Convenances et inconvenances du corps. Textes rassemblés par Marianne Stubenvoll), 20 (1998) 3, 57-68.

${ }^{44}$ Myriam Greilsammer notes that the law takes account of possible parental complicity. Such parents were probably not opposing the marriage because it had already been consummated, or even because they had been compensated financially. M. Greilsammer, "Rapts". In our dossiers we are more likely to see the parents of the opposing party at work.

${ }^{45}$ Remarkably enough, only in one case both families were actively contesting the marriage. G.S.A.B., Privy Council, 651/A, Vandersluys/Petit, 1762.

${ }^{46}$ General State Archives Brussels (hereinafter G.S.A.B.), Council of Brabant ("Officie Fiscaal"), 9480, de Steingen/Mortgat, Council of Brabant at the Privy Council, 22 April 1749.
} 
On the whole, parents had the reins firmly in hand, not only with regard to the minor, but also with regard to the young adult. The difficult position of the former goes without saying, yet in many cases the authorities themselves took an interest in the parents of the seducee. Especially the exact time they became aware of the relationship was asked for. If that time was situated conspicuously before the moment the two partners plighted their troth, or before the moment the parents effectively reacted, it was assumed that the latter were to some degree at fault. Not in the sense that they were insufficiently vigilant, but in the sense that they themselves were suspected of having wanted it that way. From the law suit De La Motte/Van Den Bossche, for instance, it appears that the father of Marie Anne De La Motte himself had initially introduced his friend and business partner Jean Van Den Bossche to his daughter, as various witnesses could testify. ${ }^{47}$ The case is particularly interesting because it appears paradigmatic, in several senses, for the problem investigated here. First there was the age difference between both partners: the girl was 24 , the man 40 . Secondly there appear to have been other candidates for the girl. And thirdly, the man who wanted to marry the minor daughter turned out to be an intimate friend of the house, particularly of the father, his partner in business. Added together, the insinuations uttered by witnesses that the father of Marie Anne De La Motte at first actually wanted the young woman to marry his friend, seem comprehensible for more than one reason. Becoming 25, his daughter was only months away from choosing a future husband without any legal means for the father to intervene. In this view, the fact that other candidates were mentioned cannot be a coincidence. Moreover, both the father and the daughter had to admit they were in financial debt to Jean Van Den Bossche for at least 300 guilders. The latter was said to have promised to return the written promesse de mariage at the very moment the debt was repaid, and one of the witnesses was actually voicing the opinion that he was incontournable for the father more than for the girl. Several times both candidates in marriage mentioned the fact that her father had originally consented to the planned marriage. According to the mistress of the house where Marie Anne stayed at the time, only Jean Van Den Bossche - besides her father - was allowed to speak to her. After at least one visit to Marie Ann, Jean Van Den Bossche was actively and explicitly encouraged to stay and keep the young woman company the moment the father left. According to Van Den Bossche himself, the father had granted him, "for once and for all", permission to visit her and "take tea and chocolate". The impression seems more than grounded that the father only opposed the marriage when the 'negotiations' foundered. From then on the gap between the two friends widened. De La Motte did not explicitly stress the lower status of Jean Van Den Bossche, who was only a 'cabaretier' or inn-keeper while the first was secretary to one of the highest courts of the Southern Netherlands (the Grand Council of Mechelen), but the latter was going to great lengths to make others believe he was actually at the point of becoming an office-holder himself ('schout' at Heist-op-den-Berg), which was only a matter of some 6000 guilders, he boosted. Van Den Bossche was thus aware of his lower status and used his financial strength to compensate it. Secondly he insinuated that Marie Anne was pregnant, or if she wasn't, that she could easily become so. From then on, positions hardened, up to the point Jean Van Den Bossche suggested Marie Anne to leave Mechelen in order to hide in Brussels. His goal was not to disappear with her or to fulfil all formal obligations of a marriage (they already had made written promises) but to put her

\footnotetext{
${ }^{47}$ G.S.A.B., Grand Council of Mechelen, 174, De La Motte/Van Den Bossche, 1715.
} 
father under more pressure. He didn't even travel along with her but stayed with De La Motte, so negotiations could continue. Later on, the father and Van Den Bossche travelled together to Brussels, "for business", as they called it. In short, the final turn of father and future son in law to the classical arguments and institutions (temporal authorities for the father, ecclesiastical for the couple), is to be situated in their wider interests and strategies.

To put it briefly, marriage was a matter of furious negotiation, not between youngsters and parents but between adults, over the heads of minors. In some cases, when they went somewhat too far, the parents or guardians of minors were actually punished or sanctioned themselves, ${ }^{48}$ for instance in the De Wever/Cooman case, where the father of a minor girl who had sought refuge in a cloister had come to gather her at the gate with armed friends and military display. ${ }^{49}$ This excessive use of parental power (according to the Privy Council), would finally turn against him in the course of the legal dispute. More generally, minors were often literally locked up, if not in a cloister, then at least in the parental house, where, to give an other clear example, Louise Reyvaert de la Potterie slept beside her father's bed. ${ }^{50}$

The exact content of the negotiations between adult 'partners' then, is another question, although we should not foster too many illusions about this. In 1753, when Catharina de Reymaecker was even abducted by her own guardians, the 'reason' for this is not too difficult to discover. As an orphan who, at her elder sister's death four months earlier, had inherited all of her parents' goods, this nineteen year old suddenly became an interesting catch. The problem was that she was currently working as a maid for a butcher who, moreover, may well have been in love with her. This was, of course, beneath the dignity of her guardians (who are referred to as leasehold farmers). The situation escalated up to the point the guardians attempted to remove the girl from the butcher by physical force, an attempt which the butcher and his friends ultimately managed to foil. ${ }^{51}$

\section{Parental motives in the law suit dossiers}

In every lawsuit the parents opposing the marriage were defending a certain position. The question now is why and when. ${ }^{52}$ Firstly, not even $9 \%$ of the arguments raised by parents in opposition to a marriage were related to the minority of their son or daughter, although legally this was the most relevant argument. The behaviour of their own child also seldom seems to have bothered them, namely in less than $6 \%$ of the cases, which only goes to confirm the thesis expanded above. The reputation of the lover of the minor was more sensitive. About $20 \%$ of the arguments raised against these marriages had to do with the past or present behaviour of the seducer or seductress. Surprisingly enough the reputation of his or her family was seldom mentioned. It was raised as an objection in about $3 \%$ of the cases only. Closely connected to reputation were objections regarding the pedigree of the candidate.

\footnotetext{
${ }^{48}$ See amongst others: G.S.A.B., Council of Brabant, 9545, Catharina De Reymaeker, 1753; G.S.A.B., Privy Council, 1298/B, Hennekinne/Culot, 1768; G.S.A.B., Privy Council, 1298/B, Fraeys/De Man, 1768.

${ }^{49}$ G.S.A.B., Privy Council, 1298/B, de Wever/Cooman, 1765.

${ }^{50}$ G.S.A., Council of Flanders, 23 368, Garcie/Reyvaert, 1760.

${ }^{51}$ G.S.A.B., Council of Brabant, 9545, De Reymaeker, 1753.

${ }^{52}$ The statistics that now follow are somewhat arbitrary. I have tried (in the case files in which it was possible) to isolate the voiced arguments neatly. In general it was possible to find various motives in a single law suit. Some of those arguments surface more often than others. It was not always advisable to count all of them, as they were often repeated pro forma and adopted by other institutions.
} 
While the previous category only takes account of concrete arguments such as bankruptcy, civil and criminal convictions and other irregularities, here all sorts of vague references such as birth, position, station and so forth come into play. Immediately we find ourselves in the principal category. 34\% of the arguments gave no more than a vague indication of pedigree as an impediment to the marriage, generally without any concrete specification. The final category is somewhat more specific and consists of (often veiled) indications that the candidate in question could not come up with sufficient money. In more than $16 \%$ this appears to have been the primary problem, although we must immediately add that the distinction between this and the previous category is somewhat artificial. Indications such as 'position', 'suitability' and 'inequality of station' do not specify whether it was professions, titles or purely financial criteria that were being cited as an impediment to the marriage.

Summarized, we actually know no more than that the core of the problem must be sought in the latter two categories. Together they represent more than $50 \%$ of all the arguments. In order to attain a more decisive percentage, the reputation of the candidate must also be included, and that immediately gives us another slant on the previous two categories. It is indeed surprising that the reputation of the woman or man in question was often mentioned and that the reputation of the family was not. The importance of 'birth' is hence qualified and the pendulum swings to the present situation of the candidate. It is difficult to prove but far from inconceivable that the future prospects of a particular candidate were gradually becoming a more important factor than his or her past. ${ }^{53}$ It would be interesting to investigate how far this quite logically gave rise to more aggressive or at least more active marriage strategies. Those who are looking to the future build in the possibility of change, unlike those who focus on the past. Which group puts the existing taxonomies under pressure, if - as seen - it was not purely the youth, requires further investigation. What follows below should in any case not be forgotten, namely that shifts were taking place in the social profile of the litigants.

\section{Significant shifts: social relations and gender}

\section{Changing profile of the protagonists}

Prior to the end of the 1750's, a fairly predictable and stable pattern was emerging. The great majority of the seducees (about $75 \%$ ) came from the aristocracy and the higher ranks of officialdom. In general they were seduced by persons at various levels of the lesser social categories, especially from the trades and lower middle classes. Men from lower urban milieus were trying to seduce young ladies from the elite groups. Confusing is the relatively high number of seducers who were in the upper echelons of society themselves, yet virtually all were offspring of high-ranking officials who were trying to land themselves daughters of the aristocracy; only one case deviates from this pattern. From the late 1750's on, the picture changed.

\footnotetext{
${ }^{53}$ Research into the perception of time is still in its infancy. A general, and then primarily linguistic, approach to past, present and future: Reinhart Koselleck, Le futur passé, contribution à la semantique des temps historique, (Paris, 1990). A more historiographic study inspired by Koselleck is: F. Hartog, "Temps et histoire, comment écrire l'histoire de France?", Annales. Histoire, Sciences Sociales, 50 (1995), 1219-1236. Marc Jacobs focuses attention on the importance of the past in establishing rights, privilege and entitlement: Marc Jacobs, "Zonder twijfel dat waarschijnlijk... Ambachtelijke geschiedenissen in de Zuidelijke Nederlanden aan het einde van het oude regime", Werelden van verschil, ambachtsgilden in de lage landen, eds. Catharina Lis \& Hugo Soly (Brussels, 1997), 243293. The common ground of these authors is their interest in the 18th century.
} 
People from the very lowest ranks of society began to appear more regularly and the category immediately above them increased as well. A smaller increase took place in the group composed of people who followed the liberal professions. The overall picture is a greater spread of seducers, but there was also a greater spread of seducees. Relatively speaking the aristocracy figured in fewer cases, but it is important to note that they were not any less desirable on the marriage market. After all, seducers from the higher ranks of officialdom were also appearing relatively less often in the second half of the century. On the whole, the phenomenon had shifted somewhat to the lower rungs of the social ladder. A measurement in which each of the people appearing was given a number based on their origin resulted in an average value of 2.8 until 1758; an increase to 4.1 between 1758 and 1768; and a drop back to 3.6 after $1768 .^{54}$ In other words, after an upheaval (of the number of 'lesser' individuals involved) around 1758 the figure appears to have stabilised somewhat. A second indication, and here the figures concerned are less influenced by a possible changed attitude of or with regard to the courts, is the average social gap between the two marriage suitors. Again we measure this by giving each person a value based on his or her category, after which we calculate for each period the average difference between the seducer and the seducee. Between 1700 and 1758 this gives a result of 2.0, between 1758 and 1768 a result of 2.6. The difference is not spectacular, but alongside the previously determined lowering of the average origin it is just as impossible to ignore. The rise in the social gap will not, however, really continue after the late 1760 s but stabilise itself at an average of 2.3. Since all this not necessarily indicates that young protagonists on the marriage market grew to be more enterprising, we have to wonder if the marriage market wasn't under a growing pressure, precisely because it became more difficult to marry within ones own station.

Still, we must move very carefully here. An increasing average gap between seducer and seducee not necessarily entails an average wider gap within each couple taken apart. Moreover, measuring this gap we stumble upon the near impossibility of establishing a precise hierarchy of social groups. Our attempts to do so, at first sight, gave a clear picture: first came the aristocracy, second the upper ranks of officialdom and the more prosperous merchants or entrepreneurs. Third came the liberal professions, for example doctors and jurists not in high office. Four: the lower ranks of officialdom, especially at a municipal level. Five included primarily the smaller entrepreneurs and merchants. Six was composed of the trades, together with some soldiers, innkeepers, a sexton and those fathers who were simply referred to as 'bourgeois'. Seven, finally, consisted of vagrants, maids, servants, libertines, adventurers and so forth. Thus is the ranking as we used it to make our calculations, but it is far from self-evident. As will become clear, especially the merchants or entrepreneurs are very difficult to situate. They figure in category two as well as in five, yet it is possible that in certain cases they belong lower, for example after a bankruptcy, and not seldom it is evident they saw themselves as high as in the first, or even higher. The problem is, there are no absolute criteria to measure or value social groups. This becomes particularly problematic if we consider that individuals and social groups themselves were at the time uncertain about changing criteria, values, norms and perceptions. As we shall see, potential criteria were precisely at stake in some of these conflicts. Especially between nobility and rich entrepreneurs

\footnotetext{
${ }^{54}$ Both dates, 1758 en 1768, are chosen regarding important, trend setting cases that occurred then.
} 
or merchants there seems to have emerged a certain confusion. When did financial assets, for instance, outrank traditional titles and pedigrees?

\section{Relationships between the various social groups}

A difficult to perceive but no less significant shift occurred in the relationship between the various elite groups. Law suits between two aristocratic families seem to have occurred less from mid-century on, which calls to mind what has already been asserted, for instance, for England: aristocratic circles preferred not to rely upon the authorities to solve such problems. ${ }^{55}$ As a result, the nature and course of lawsuits in which one half of the couple in a disputed marriage came from the aristocracy, attract our attention. To begin with, only exceptionally a son or daughter of aristocratic parents came out of the lawsuit as 'the winner' in the first two decades after 1750 . Even a thirty-year-old was unable to escape from parental control. ${ }^{56}$ Yet the aristocratic families in question were far from flourishing. A highly interesting illustration of this occurs precisely in 1758. A merchant, the son of an official, hazarded the seduction of Marie Anne de Groote. At a certain moment the guardians of the girl themselves argued that she was not wealthy enough to marry the merchant. They said her future husband should have to come from a better family, because she herself had insufficient means to provide for herself according to her station. ${ }^{57}$ Consequently, the question whether or not these aristocratic families were appearing in the law suits because of their financial decline in relation to other classes - precisely because an alliance now seemed within the reach of nonaristocratic families - begs to be answered. In the first contacts between the high aristocracy and the merchant classes the pleasure was undeniably on the part of the merchants. Upon closer examination this pattern appears to have continued throughout the whole of the eighteenth century. After 1757, each time an aristocratic family came into conflict with a merchant family, it was the aristocratic family that was opposing the marriage. If such conflicts occurred more frequently after midcentury, it was either because the sons and daughters of merchants were trying their luck more often or because the aristocracy was quicker to resolve the matter with a lawsuit. Both options have a conservative connotation. Anyhow, the aristocracy did not grow to be any less desirable on the marriage market. Even if the younger generation would be more inclined to break through established social barriers, the inclination would still be, in a sense, a conservative one. Perhaps what we are witnessing here are two closely intertwined movements. Aristocratic families were probably losing more financial muscle than prestige. And because of their own financial power, or because of the financial weakness of the aristocracy, primarily merchant families found themselves in a position to hazard alliances. These alliances did not bring them increased wealth but increased status, a better name or a more permanent consolidation of their purely financially superior position. ${ }^{58}$

Significantly, we do not witness the same pattern with regard to the aristocracy and the higher ranks of officialdom. Between those two the scales were in balance, albeit that more law suits now occurred. When we complete the triangle with the marriages

\footnotetext{
55 J. Cannon, Aristocratic Century, the Peerage of 18th Century England, (Cambridge, 1984), 79ff.

${ }^{56}$ G.S.A.B., Privy Council, 1298/B, Hennekinne/Culot, 1768.

${ }^{57}$ G.S.A.B., Privy Council, 1298/A, de Groote/De Maeght, Impératrice Reine..., f॰ 4, p. 1, art. 3, 7/7/1758.

${ }^{58}$ For a comprehensive history of the aristocracy in the Southern Netherlands: P. Janssens, De evolutie van de Belgische adel sinds de late middeleeuwen, (Brussels, 1998).
} 
between merchant families and the families of high-ranking officials, the children of the latter seem to have been the most desired on the marriage market. Of the 16 times ${ }^{59}$ the upper ranks of officialdom appeared in the law suit dossiers after 1768 , they were the desired party no less than 13 times. We could thus say that office was an appealing asset. However, precisely the fact that as many boys as girls were desired suggests immediately that the attraction was about more than the office per se. The attraction may again have reflected the status that office conferred, the financial muscle of the holder of the office, the name and the reputation of the family, or perhaps even the external trappings of that office. It could be argued that officeholders owned the best mixture of financial and symbolic capital, whereas nobility and rich bourgeoisie lacked either the former or the latter. In any case, it is clear that both financial and symbolic categories must be taken into account, just because they can't be separated in reality. Recently, for example, Thomas Luckett observed that commerce functioned as a school of honour, since prestige and reputation - and thus trust - stimulated economic transactions. ${ }^{60}$ More general it was Pierre Bourdieu who pointed to the relationship of socio-economic capital on the one hand and symbolic capital on the other. The French sociologist saw it as a dialectical or at least inversely proportional relationship, in that 'le capital symbolique' might be a kind of repressed or denied capital, but still the only sort of capital available for accumulation in the absence of economic or social capital. ${ }^{61}$ Historians have often underestimated the consequences of this kind of insights on a personal level, among others because of the abstract character of the theories involved. More recently however, emphasis in the social sciences shifted from structures and abstract categories to practices and concrete contexts. The question now is how individuals interact with others in specific situations and circumstances. French sociologists have elaborated the so-called 'convention-theories', trying to grasp how individuals cope with reality in specific situations and how they justify their actions. In those situations, conventions are the unwritten but mutual understandings, the shared skills, but at the same time they constitute the norms one has (unconsciously) to live by. ${ }^{62}$

Women: towards emancipation?

In any case, the most striking shift has to be sought elsewhere. Before the 1750's only occasionally (less then 15\%) seducers appeared to be women. Yet immediately after 1754, the moment we witness our first case of a women seducing a (younger)

\footnotetext{
${ }^{59}$ More precisely: of the sixteen times that the parties opposing them could also be accurately situated.

${ }^{60}$ Thomas M. Luckett, "The debate over imprisonment for debt in eighteenth century France", in Des personnes aux institutions. Réseaux et culture du crédit du XVIe au XXe siècle en Europe, eds. L. Fontaine, G. Postel-Vinay, J.-L. Rosenthal and P. Servais, (Louvain-La-Neuve, 1997), 163-172.

61 "le capital symbolique est ce capital dénié, reconnu comme légitime, c'est-à-dire méconnu comme capital (...) qui constitue sans doute (...) la seule forme possible d'accumulation lorsque le capital économique n'est pas reconnu". Pierre Bourdieu, Le sens pratique, (Parijs, 1980), 200-201.

${ }^{62}$ Luc Boltanski \& Laurent Thévenot, Les économies de la grandeur, (Parijs, 1987); Luc Boltanski \& Laurent Thévenot, De la justification. Les économies de la grandeur, (Parijs, 1991). For a brief introduction in the so-called 'convention theories' (from an economical point of view): J.-P. Dupuy, F. Eymard-Duvernay, O. Favereau, A. Orléan, R. Salais and L. Thévenot, "Introduction", Revue Économique, 40 (1989) 2, 141-145, (Introduction to a special number about 'L'économie des conventions'). For an 'application': Luc Boltanski, L'amour et la justice comme compétences. Trois essais de sociologie de l'action, (Paris, 1990).
} 
men, this increased to almost $50 \%$. Although the figure also stagnated at some $36 \%$ from 1768 on, it is a striking change. Let us trace a short history.

In 1754 a certain de Coulemont fled to France. His resolve to marry was being opposed by his parents so he wanted to wait elsewhere until he attained the age of majority. In the Southern Netherlands even the threat of 'private confinement' was hanging above his head. The full facts of the matter are unclear. We are not even sure if the man really wanted to marry. Sometimes he seems to have ravished the woman, who was therefore demanding her rights. For the women, the court should order de Coulemont to fulfil his promises ("accomplir ses engagements"). ${ }^{63}$ In the law suit which followed immediately after this one however, once again the girl had seduced the boy. Neither had attained the age of majority - she was twenty-three and he was twenty - but only his parents were opposing the planned marriage. ${ }^{64}$ Given their age, the significance of this law suit could be qualified, were it not that in the law suit immediately afterwards, in 1757, it was again the woman who can be seen as the seducing party. The true story is only partially revealed by the dossier, but it is clear that here too the lovers differed little in age - the boy was 19, the girl at most a few years older - and that the girl's father was straining to ensure that his daughter's marriage to this son of the aristocracy took place, a plan that would ultimately fail. ${ }^{65}$ Thus far, the empirical facts give the impression that this relatively new form of rapt was originally rather 'innocent'. The small age difference increases the likelihood of 'modern' love, also because the precise roles played by both members of the couple were unclear. Cases like the seduction of Antoine Plantefeve however, were of a very different nature. The, according to his family, feeble-minded Antoine was seduced by a certain Dorothee Block, a creature with a somewhat lower station. We can of course never exclude the possibility that she had indeed fallen spontaneously and genuinely in love with this forty-five year old bachelor, but the arguments of family and authorities are fairly convincing in indicating the contrary. ${ }^{66}$ Idem ditto a year later, 1760, when according to his family the twenty-two year old J.F. Schoppe was seduced by a real "adventures". 67

Considering the triangle parents, suitor and minor, it is clear who was the weakest before the late 1750s: an under aged woman was subject to both of the others. Her fate was decided for her. ${ }^{68}$ Disputes such as De La Motte/Van Den Bossche and De Neve/Ridderbosch show clearly that her future was discussed without her even being present, as we know from their personal letters. ${ }^{69}$ The often intricate attempts at escape indicate that some girls were virtual prisoners in their own homes. ${ }^{70}$ This means that parents had absolute control over whom their daughter did or did not meet. At the most she could choose from a number of candidates who had already been selected by her father, and even then she could only hope the understanding

\footnotetext{
${ }^{63}$ G.S.A.B., Privy Council, 650/B, de Coulemont, 1754.

${ }^{64}$ G.S.A.B., Privy Council, 1298/A, Vanderheeren/Loys, 1756.

${ }^{65}$ G.S.A.B., Privy Council, 650/B, Butler/Wreckem, 1757.

${ }^{66}$ G.S.A.B., Privy Council, 1298/A, Plantefeve/Block, 1759.

${ }^{67}$ G.S.A.B., Privy Council, 650/B, Schoppe/lsbecque, 1760.

${ }^{68}$ It is no accident that throughout the centuries legislation gives no decisive answer about the consent or otherwise of women in rapt. Legislators were looking for an alternative for the lack of violence towards the abducted woman, which was actually the only legal ground to impose sanctions. Only in the law suits themselves did women come to the fore.

${ }^{69}$ G.S.A.B., Privy Council, 1298/B, de Neve/Ridderbosch, 1760; G.S.A.B., Grand Council of Mechelen, 174, De La Motte/Van Den Bossche, 1715.

${ }^{70}$ See for example G.S.A.B., Council of Brabant, 8236, De Fusco/de Hulden, 1710.
} 
between her father and her future husband did not founder. In this context it is somewhat strange that women began to try what men, often in consultation with their family, were already in a position to do decades earlier. Although these lawsuits suggest that it began relatively innocently, some women soon began to behave at least as boldly as seducing men. This, however, does not unveil a kind of emancipation. To begin with, the position of most women did not necessarily improve as the Ancien Régime drew to its end. Finding a suitable husband, in the mean time, remained a necessary goal. ${ }^{71}$ But in a society with either a constantly increasing gamut of social groups, or an ever more sensitive perception of differences, it became increasingly difficult to marry within one's own group. In France, in the diocese of Meaux, this even went so far that of the 45 girls who requested a dispensation for kinship ("dispence de parenté") ten explicitly admitted that they could find nobody suitable ("de leur condition") outside their own family. ${ }^{72}$ Courtship behaviour must have changed accordingly. In our sample, two groups of seductresses ultimately stand out. More often than men they appear to have been just the spearhead of a whole family. On the other hand they were often referred to as "libertine" or "adventuress". More than three-quarters of the seductresses fall into one of these two categories. ${ }^{73}$ In both instances there is a real chance the girl was investing her body in an attempt to ensure her future. Significantly, a quarter of the seductions by women occurred in Louvain, in the vicinity of the university. Sometimes, after plighting his troth, the young man seems to have lost all desire to marry, which may indicate that he had indeed stepped into a trap. There's no need to claim that all of these women were prostituting themselves or were being prostituted, although in some cases it certainly appears to have been the case. ${ }^{74}$ The marked interest in the question of whether there was an obligation "per copulam carnalem" (through copulation) in certain cases, does at least raise suspicions. Consent may well have been given in exchange for it, as several scholars have already shown for other periods and regions.

Our hypothesis is that women were not appearing as seductress more often in these dossiers because of some longing for sexual or other freedoms, but out of necessity. They needed now to throw their body and their smile into the scales as well as their pedigree and their dowry. In the first half of the eighteenth century it still happened that a man claimed a woman who 'was promised to him'. ${ }^{75}$ This phenomenon seems to have disappeared after 1750 , but at the same time some women had difficulties in finding a suitable match. Yet even more than for men, it was necessary socially to get married. The means women employed to find a husband were those closest to hand, and they tied in perfectly with familial strategies. ${ }^{76}$ It is advisable here to

\footnotetext{
${ }^{71}$ For the interaction between economic conditions and the marriage market, especially with regard to women, see: Olwen Hufton, "Woman, work and marriage in eighteenth century France", in Marriage and Society, ed. R.B. Outhwaite, 186-204. More general: Olwen Hufton, The Prospect Before Her, a History of Women in Western Europe, (London, 1995).

${ }^{72}$ Jean-Claude Bologne, Histoire du Mariage en Occident, (Paris, 1995) 246.

${ }^{73}$ Of the 18 sufficiently comprehensive dossiers (of the 27 ), 9 can be classed as 'a family offensive', in 5 cases the woman in question was referred to as 'libertine' or more usually 'adventures'. That made $77.7 \%$.

${ }^{74}$ See for example G.S.A.B., Privy Council, 1299/C, Van Outheusden, 1769; G.S.A.B., Grand Council of Mechelen, 174, De Le Motte, 1715; G.S.A.B., Privy Council, 1298/B, Ridderbosch, 1763.

${ }^{75}$ See especially G.S.A.B., Grand Council of Mechelen, 289, Steenemeulen and Mereman/Schote, 1701; G.S.A.B., Council of Brabant, 8209, Falhay/De La Chambre, 1711.

${ }^{76}$ An article (about France) that does not expand upon this thesis but does confront gender differences and differences of background (aristocracy/bourgeoisie) with each other in a politicaljuridic context: $\mathrm{H}$. Benveniste, "Les enlèvements".
} 
remember what was happening in Brittany, France, in the first half of the eighteenth century. There, every illicit sexual act was seen as a form of rapt. The 'ravisher' or 'abductor' was given a choice between marriage or death. ${ }^{77}$ According to this logic, it was possible to take advantage of a man or a woman in a weak moment and to ensnare them for life. It would at least be worthwhile investigating whether this was one of the reasons why seductresses appeared more often in the vicinity of Louvain University, a place where men may well have been more vulnerable. Inversely, it could be argued that women were more vulnerable than before on a more fundamental level. Referring to Bourdieu again, the symbolic had also a 'violent' side, be it invisibly. ${ }^{78}$ Bourdieu understood 'symbolic violence' as the result of incorporated norms, tastes and values that instigate individuals to long for precisely what 'society' already 'prescribed'. That is why what young seducing women wanted was perfectly in tune with what their family wanted: a good and prestigious marriage. The difference of this view with Paul Griffiths' - who argued that young women agreed to sex with marriage in mind and thereby used conventional opinion about their socalled weakness in their favour $-{ }^{79}$ is that symbolic violence works unconsciously, on a level where a close connection between sexuality and prestige can be assumed.

From the 'weak' women to the 'weak' minor?

In the mean time, authorities were remarkably lenient with so called 'ravishers'. After 1768 the marriage simply went ahead in at least $26 \%$ of the cases. Of the total of which we know the ultimate outcome, ${ }^{80}$ this percentage rises to $53 \%$. Only in $26 \%$ of the cases is it certain that a marriage did not take place. Of the total of the known judgements, this rises to some $48 \%$. In short, the exact average, which is not to be measured on this to small sample, might be around $50 \%$, which may indicate the power of the church, but also a certain degree of caution on the part of the temporal authorities.

Upon closer examination this mildness was one-sided and primarily concerned the seducer. At the beginning of the 18th century there were still a few instances of banishment - not always implemented - but little by little the active party appears to have escaped any sanction. Attention shifted to the 'victim', the usually under aged seducee. Bearing in mind a stimulating article by M. Mitterer, who examined shifts in France, we can trace the legal evolution. ${ }^{81}$ Charles V's ordinance of 1540 only imposed a disinheritance of the seducer with regard to goods coming from the seducee, but by 1623 one's own child could also be disinherited. The ordinance of 1692 went even further. Parents became obliged to disinherit their own child, a measure they probably welcomed not always entirely happy. ${ }^{82}$ Despite the fact that the minor (in a certain sense the weaker party) was thereby being found at fault, he or she was not so much punished as brought to safety. The role of the Privy Council can be seen as setting the example here. The trend was that the Privy Council, following the lead of lower authorities and the provincial councils, started to sanction these minors with private confinement. The council was not particularly keen on the

\footnotetext{
${ }^{77}$ M. Mitterer, "Der Rapt de séduction als Ehehindernis nach gallichen Kirchenrecht”, Zeitschrift der Savigny Stiftung fur Rechtsgeschichte, 12 (1922), 85-92.

${ }^{78}$ For the 'symbolic violence' on a marriage market: $P$. Bourdieu, La domination.

${ }^{79}$ Paul Griffiths, Youth and authority. Formative experiences in England 1560-1640, (Oxford, 1996).

${ }^{80}$ I have been obliged to distinguish between 'provisional outcome' and 'final outcome'. The first category is often a referral, usually by the Privy Council to lower courts.

${ }^{81}$ M. Mitterer, "Der Rapt".

82 See amongst others Jean-Louis Moreau, La guerre.
} 
private confinement of minors. It is true that the new procedure it introduced in 1758 - the suspension of the procedure before the court of the Officiality ${ }^{83}$ - often went hand in hand with the private confinement of the minor, but in all cases that confinement was only provisional. For a final ruling the council consistently referred the case to the "juge competant" (competent judge) and only in 5 cases did the council opt directly for a brief confinement. Moreover, the latter decision can easily have been influenced by the minor's fear of his or her parents. The young people in question were often anxious about the mental and physical violence that may well have awaited them at home after their escapades. In some cases their attempt to flee and their decision to marry was already provoked by an intolerable situation at home. Some $18 \%$ of the arguments minors used in the lawsuits were related to physical or emotional abuse by their parents. Consequently, it is certainly not out of the question that in a number of cases private confinement was the least unsatisfactory solution, even for the minor in question. Not coincidentally, some of the seducees were married off immediately after the drama. References to potential partners the parents had already lined up for them were sometimes already being made during the lawsuits. The de Neve boy was even married off to his niece whilst the law suit was still in progress and a similar fate befell daughter Hennekinne. In a lawsuit at the end of the 17th century, Angeline Van Eyck turned out to have been destined for the convent anyway. ${ }^{84}$ In this context, it is not surprising that after seeing her plans to marry founder, somebody like Antoinette de Arberg asked the Privy Council to permit her to stay in the convent a little longer. ${ }^{85}$

All this, of course, does not alter the fact that it was no longer the seducer, thus the 'aggressor', who was being locked up, but the seducee or the passive or 'weaker' party. Although private confinement was not necessarily regarded as a punishment, the fault was seen to lie in the confined person. Even if the minor was not the immediate cause of the problem, it was still in the minor that it had to be tackled. In other words, the problem was not the fault of the weaker party, but a weakness within the weaker party. Anxiety was focused on the invisible, the latent, the unconscious. It is striking here that in each case the authorities and especially the parents were anxious to ensure that the minor had absolutely no contact with the seducer; not personally, not physically and not by correspondence. This anxiety was therefore about more than a written promise of marriage or sexual intercourse possibly resulting in pregnancy. The anxiety was about the psychological influence of mostly older lovers: anxiety about infatuation, passion or love. Therefore, it is possible that minors, not women, were perceived as the most vulnerable from then one. In order to understand this, let us call into mind some important ideas John Forrester has formulated. Trying to relate the notion of contract and the ideal of freedom - two fundamentals in Western society - with practical and theoretical aspect of psychoanalysis, Forrester stumbled upon questions about free love and seduction. He tried to understand why 'a seduction that is viewed from the standpoint of a questioning of the status of the consent will always be confused with rape, ${ }^{86}$ Any time a minor gives way to the opposite sex, aggression is inherently present.

\footnotetext{
${ }^{83}$ Ibidem.

${ }^{84}$ G.S.A.B., Council of Brabant, 8063 and 5610, Van Eyck/Le Roux, 1694.

${ }^{85}$ G.S.A.B., Council of Brabant, 9294, de Arberg/de Gironde, 1747.

${ }^{86} \mathrm{John}$ Forrester, 'Contracting the disease of love: authority and freedom in the origins of psychoanalysis', in The Anatomy of Madness: Essays in the History of Psychiatry, eds. W.F. Bynum, R. Porter and M. Shepherd, (Londen, 1985), 2nd vol., 255-270. Reprint in J. Forrester, The Seductions of Psychoanalysis. Freud, Lacan, Derrida, (Cambridge, 1990).
} 
Indeed, Forrester soon found out that only when viewed form the outside free choice is a salient feature of love: 'if love were experienced as a free choice from the inside, it would not have the quality of being taken over by the object that is its hallmark, making it so longed for and dreaded. Seduction is thus the mediation of freedom and slavery in the sphere of love. ${ }^{87}$ The implications for our thinking about free or modern love are far from insignificant. The 'object' Forrester is referring to is of course a psychoanalytical notion, but can be understood as part of the mentioned 'symbolical violence' as well. The physical nor the mental aspects of love can be seen apart from the cultural and symbolic context the protagonists are socialized in. Youngsters unconsciously learn to desire specific internal and external features of the opposite sex.

In a way, therefore, it seems almost logic that by the opposing steps of parents, 'it is the authority of a subject vis-à-vis their own desires which is brought to the fore'. ${ }^{88}$ From a legal point of view, rapt has evolved over the centuries from a form of physical violence into a more intangible sort of aggression. Originally there could only be talk of a penal offence when violence, either against the minor or against the parents, could be proven. At least in France, there is an evolution traceable in which the violence was gradually superseded by artifice, until at a certain moment an incontrovertible presumption of séduction was taken for granted in every marriage of a minor without parental consent. ${ }^{89}$ From then on, rapt and séduction met. When in the following 'responsibility' was placed firmly on the shoulders of the victim, the most dependent party, the one who let him- or herself be led astray, rapt de séduction became a sort of violence that could no longer be controlled. This form of aggression could not even be held back by walls, and a man was no less susceptible to it than a woman. ${ }^{90}$ Perhaps anxieties about passion only really set in after 1750 , when this 'derangement' was no longer a purely female condition. In this way there was indeed talk of a greater sensitivity for affection, albeit with completely different connotations.

\section{Conclusion}

Sara Grieco sums up that a change in attitudes towards sexuality took place in the latter half of the 18th century. Especially amongst the middle classes and the aristocracy, an aspiration characterised by the merging of love, sexuality and marriage is seen to have manifested itself. ${ }^{91}$ This opinion is often based on an assumed greater economic latitude for women and fits in perfectly in the history of the modern 'feminised' family, in which England is seen to be a forerunner. But the question remains to what extent women from the elite groups indeed enjoyed more independence as the early modern times progressed. In this article, we have

\footnotetext{
${ }^{87}$ John Forrester, "Rape, seduction and psychoanalysis", in Rape, eds. S. Tomaselli and R. Porter, (Oxford \& New York, 1986), 80.

88 J. Forrester, "Contracting", 265-266.

${ }^{89}$ The shift from abduction with violence to abduction by seduction has until the present day been primarily - or exclusively - examined juridically, most thoroughly (for France) by M. Mitterer, "Der Rapt".

${ }^{90}$ In the law suit Van Eyck it is striking how the runaway daughter Angeline was joined immediately after her arrival in a convent by an aunt, who did not attempt to get her to leave but did constantly try to talk her around. G.S.A.B., Council of Brabant, 8063 and 5610, 1694.

${ }^{91}$ Sara F.C. Grieco, "Amour et sexualité", in Histoire des femmes en occident, eds. G. Dubuy \& M. Perrot (Paris, 1991), 74-94.
} 
postulated that certain women, and not only those of the lower social strata, began to invest their bodies in a bid to improve their future. It looks like sexuality and marriage indeed intertwined, be it that 'free choice' and 'affection' as we understand it today, were not the determining factors. The actions of the adult women who appear in these dossiers seem often cold and calculated. In stead of passionate, one party acted rather rationally, and only the seduced party let him- or herself be carried away. Especially minors were susceptible to sentiment, as well as to private confinement. Looking for "victims" of conservative parents, we do not stumble upon young couples but on minors, who did not have a say in these conflicts and lawsuits and where victim of both parents and much older seducers or seductresses. Moreover, the constantly returning lament of parents about 'the folly of youth', 'the blindness of love' and so forth may not be dismissed as merely rhetoric. Parents were undeniably anxious about the follies of their children; they feared that their socalled 'blindness' would be abused. In order to grasp the deeper meaning of this, we have to situate the manifestation of such anxieties in the socio-economic and symbolic context of that time. Feelings and sentiments cannot be seen apart from the interests, contexts and symbolic repertoires which were active at that moment. The idea of a more aggressive or more opportunistic marriage strategy, for example, must be seen in relation to a complex social reality.

Scrutinising these 90 dossiers, we could not detect a generation-conflict between 'youngsters' and adults. To be sure, these series of conflicts do not support the conclusion that we witness changing courting customs or habits at all, let alone changed attitudes of young 'libertines'. First of all, one party of the couple wanting to marry was not even young. Both the feminine and the masculine seducers tended to be a lot older than the seduced minor. They were in their late $20 \mathrm{~s}$, not seldom even older than 30, while the minor was, as a rule, under 25 . Secondly, all reference to different sets of values or norms between parents and the younger generation lacks. Most often the seducing party came from the inner circle of friends and relatives of the family who was opposing the marriage, and any trace of an alternative youth culture concerning courtship and marriage, is absent. In fact, the cleavage between the two partners was as great as the cleavage between the two opposing families. What we are witnessing here, is a struggle between social groups who are trying to consolidate or strengthen financial or symbolic positions via the marriage market. After a young orphan from a rich but non-aristocratic family was seduced by the son of the impoverished Baron van Lovendeghem, her guardians cited precisely the difference in birth as a primary reason why the marriage should be allowed to go ahead: "there is no reason to oppose this marriage, because although [she is] more wealthy than the aforementioned chevalier, this does not provide valid grounds to oppose the marriage (...) since it is well known that the aforementioned chevalier is, in compensation, of more elevated birth." 92 Remarkably, during the 18th century status and material wealth appear to have been negotiable, something which has already been found for France: "Between those who seek to purchase a title and those who wish to regild their blazon alliances are being forged which are condemned by both aristocratic and bourgeois morality." 93 Following sociologists and anthropologists who seek to understand the relationship of one's position in a social 'field' on the one hand and his or her most intimate feelings and desires on the other,

\footnotetext{
${ }^{92}$ G.S.A.B., Privy Council, 1300/B, Lovendeghem/Zaman, petition by Marie Therese Zaman to the Privy Council, 31 October 1775, p. 2.

${ }^{93}$ Jean-Claude Bologne, Histoire, 140.
} 
one could conclude that changing courtship behaviour of youngsters must first of all be linked to changing power relations between different groups on the marriage market.

Given the disappearing notion of the 'promising' of a girl to another man or family, it is possible that 'traditional' customs or habits were under pressure. The parallel appearance of 'seducing' women and the sudden increase in the number of law suits point in the same direction. Still, it is not a surprise that the most desired parties on the marriage market seem to have been exactly those groups who are often labelled 'traditional'. In the same vein, the putative increased freedom of courtship for women is very misleading, given their inferior economic and social status. Their economic and symbolic dependency on men must have reflected itself on the marriage market and on their most intimate desires. Even if the 'market' was becoming somewhat more 'laissez faire', it is far from sure that most women were better of than before. ${ }^{94}$ Marriage had an overwhelming importance, for both young and old, ${ }^{95}$ and there are reasons to believe that marrying within one's own class or social group was becoming increasingly difficult, either because these groups became more exclusive in reality or because they became more narrowly perceived. Especially for women this might have been a serious problem. It would be interesting to compare eventual fluctuations on the marriage market with the population pyramid, if possible subdivided according to class and sex. In depth demographic studies could prove worthwhile. $^{96}$ The role of cloisters certainly also deserves more research. We know that they functioned as a safety valve on the marriage market and that they offered sanctuary to unmarried members of the elite groups. Some indications suggest that the entry in them became problematic around $1750 .^{97}$ But finally we must be careful not to relate the occurring problems solely to hard demographic or economic determinants in a mechanical way. The most striking transformation found in the Austrian Netherlands is the tendency to locate the 'problem' in the ungraspable feelings of minors, as if 'modern love' was emerging there after all. Love, however, is a very complex matter, especially from a historical point of view. It isn't a human universal waiting to be discovered, but a multifaceted mix of history and psychology, a historical interaction between social structures and contexts on the one hand and subjective sensations and actions on the other. From this point of view, considering the work of Pierre Bourdieu on marriage strategies, taste and distinction, the possibility of exchange between financial or economic forms of capital and symbolic capital in the form of honour and prestige, opens up a whole range of sociological and anthropological work for early modern historians. Combined with

\footnotetext{
${ }^{94}$ The early evolution 'from custom to contract' Martha C. Howell pointed to, might even have reduced women's rights. Martha C. Howell, The Marriage Exchange: Property, Social Place, and Gender in Cities of the Low Countries, 1300-1550, (Chicago, 1998).

${ }^{95}$ In England a case is known in which a woman promptly married another man when the groom failed to turn up for the ceremony. R.B. Outhwaite, Clandestine, 21. In our dossiers, a strikingly tenacious desire to be married is also often present, although it is sometimes difficult to determine whether somebody has gone to great lengths to find a partner, or whether somebody was able to choose between various candidates. When she met François Garcie, Louise Reyvaert had already rejected some three candidates. We could conclude from this that she was a very eligible marriage partner, but the reasoning can also be reversed. Maybe we should also examine who ultimately turned whom down.

${ }^{96}$ See e.g. Claude Bruneel, La mortalité dans les campagnes: le duché de Brabant aux 17e et 18e siècles, (Leuven, 1977).

${ }_{97}^{9}$ P. Lenders, "De Zuidelijke Nederlanden onder Maria Theresia", in Algemene geschiedenis der Nederlanden, ed. D.P. Blok, (Haarlem, 1977), IX, 101.
} 
psychoanalytical notions (of Jacques Lacan), for instance, one could detect fundamental mechanisms of authority and dependence, especially in the sphere of love and sentiment. ${ }^{98}$ Eventually, it is a historians job to find out why and where love and free choice became mutually exclusive.

${ }^{98}$ Bert De Munck, “Jawoord aan een gebod? Over daders en slachtoffers van 'Rapt de Séduction' in de Oostenrijkse Nederlanden', in Tussen dader en slachtoffer. Jongeren en criminaliteit in historisch perspectief, eds. C. Lis \& H. Soly, (Brussel, 2001), 195-226. 